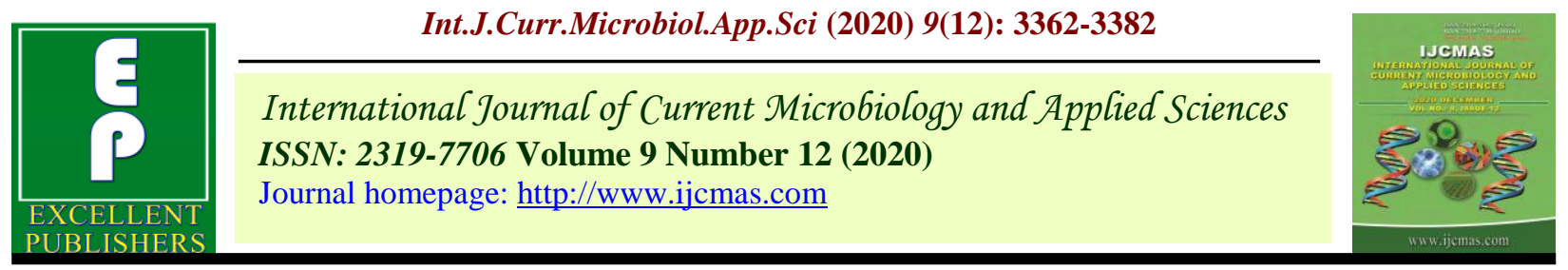

Review Article

https://doi.org/10.20546/ijcmas.2020.912.401

\title{
Beta Glucan: A Valuable Functional Ingredient in Foods
}

\author{
Mushtaq Ahmad*, Shahida Iqbal, Rizvan Rashid, Nagmana Gul, \\ Baba Ahmad Jahangir, Rukhsar Ahmad Dar, Showkat Ahmad Dar and Rohie Hassan
}

Sheri-e-Kashmir University of Agricultural Sciences and Technology, Shalimar Srinagar, India

*Corresponding author

\begin{tabular}{|c|c|}
\hline & A B S T R A C T \\
\hline $\begin{array}{l}\text { Ke y w o r d s } \\
\beta \text {-glucan, Dietary } \\
\text { fiber, Functional } \\
\text { foods, Extraction } \\
\text { methods }\end{array}$ & \multirow{3}{*}{$\begin{array}{l}\beta \text {-glucan is a valuable functional ingredient and various extraction } \\
\text { techniques are available for its extraction. Choice of an appropriate } \\
\text { extraction technique is important as it may affect the quality, structure, } \\
\text { rheological properties, molecular weight, and other functional properties of } \\
\text { the extracted } \beta \text {-glucan. These properties lead to the use of } \beta \text {-glucan in to } \\
\text { various food systems and have important implications in human health. } \\
\text { This review focuses on the extraction, synthesis, structure, molecular } \\
\text { weight, and rheology of } \beta \text {-glucan. Furthermore, health implications and } \\
\text { utilization of } \beta \text {-glucan in food products is also discussed. }\end{array}$} \\
\hline Article Info & \\
\hline $\begin{array}{l}\text { Accepted: } \\
28 \text { November } 2020 \\
\text { Available Online: } \\
10 \text { December } 2020\end{array}$ & \\
\hline
\end{tabular}

\section{Introduction}

Cereal grains produce a one seeded dry fruit called a caryopsis, (Ahmad et al., 2016a) more commonly called kernel or grain. Nutritionally these grains are a good source of carbohydrates, lipids, proteins, vitamins, minerals, and other minor components (Evers and Millart, 2002). Beta glucan is one type of valuable dietary fiber present in cereal crops, especially in barley, oat, and some mushrooms. An updated definition of dietary fiber was presented by the AACC committee in the year 2001 (Ahmad et al., 2015a) which reported that dietary fiber is the edible plant parts and analogous carbohydrates that offer some resistance to digestion and absorption in the human small intestine but partial or complete fermentation may occur in the large intestine (DeVries, 2001). The Codex Committee on Nutrition and Foods for Special Dietary Uses (CCNFSDU) illustrated that the current definition of dietary fiber should include both edible plant and animal material. However, most of the recent literature supported that the dietary fiber originate from plants. It was recommended by this Committee that the definition of dietary fiber should be amended to the current definition (WHO, 2001). The WHO 
representative offered a new concept of dietary fiber that introduces the idea of intrinsic and added fiber (WHO, 2003). The National Academy of Science proposed that total fiber is the sum of dietary fiber and functional fiber. Whereas, dietary fiber is a complex of non digestible carbohydrates (Ahmad et al., 2015a) and lignin associated with plants, functional fiber is actually the type of non digestible carbohydrates having ben eficial physiological effects in humans (Ahmad et al., 2015a; Tungland and Meyer, 2002).

Most of the definitions of dietary fiber were based on the physiological characteristics of non-digestion and non- absorption in the small intestine, together with some desirable health benefits. A latest and comprehensive definition of dietary fiber was proposed by CCNFSDU and by the Codex Alimentarius Commission (CAC, 2006). This definition declares that dietary fiber are carbohydrate polymers with at least a degree of polymerization of about three, and these are deprived of the ability to digest or be absorbed in the small intestine. According to this definition, naturally occurring edible carbohydrate polymers in food, physically, chemically, and enzymatically altered carbohydrate polymers are included in the group of dietary fiber. Furthermore, synthetic carbohydrate polymers were also covered by this definition (CAC, 2006). $\beta$-glucan is the principal fiber present in barley and oat. Although barley is an excellent source of $\beta$ glucan, yet on a world wide basis, a limited amount of the barley is also used as a source of $\beta$-glucan in various foods for human consumption but the major quantities of barley are used for animal feed (FAO, 2001). Owing to its importance the Food and Drug Administration (FDA) (Ahmad et al., 2015a) allowed its use in food products and made it obligatory for labeling requirement to acquire health claim. It was also recommended that a diet high in soluble fiber from whole oats (oat bran, oatmeal, and oat flour) should be used to reduce the risk of heart disease (FDA, 1996). In its proposal FDA evaluated several studies for the consumption of oat products, for example, muffins, breads, shakes, and entrees. On the basis of these studies, a daily dose of at least $3 \mathrm{~g}$ of $\beta$-glucan from oats was recommended to achieve (Ahmad et al., 2015a).

\section{$\beta$-glucan synthesis,}

The enzymes endoglycosynthases help in synthesis of $\beta$ - glucan molecules through catalyzation of reactions that in turn catalyze the self-condensation of sugar donors for the in vitro synthesis of a regular polysaccharide. The specificity of the enzyme allowed the polymerization of $\alpha$-laminaribiosyl flu- oride via the formation of (14)- $\beta$-linkages to yield a new linear crystalline (1 3) (1 4)- $\beta$-D-glucan with a repeating 4-glucose and 3-glucose units (Ahmad et al., 2015a); Magda et al., 2004 Ahmad et al., 2010). However, the mechanism may vary from species to species. Calcium promoted $\beta$-glucan synthase activity and promotion was also ob- served at free calcium concentrations (Paliyath and Poovaiah, 1988). Endo- $\beta-\left(\begin{array}{lll}1 & 3\end{array}\right)$ (1 4$)-$ glucanase is a thermo-stable enzyme and develops during the germination of barley; this is the major enzyme associated with degradation of the $\beta$-glucan molecule after synthesis of $\beta$-glucan thereby controlling (Ahmad et al., 2014c) the length and the molecular weight of $\beta$-glucan in cereal crops (Hrmova et al., 1997). While in microorganisms (in vivo) a different situation exists, the structure of $\beta$-glucan is engineered under strict control of genes. To understand this structural phenomenon, two genes, KRE6 and SKN1 of Sacchromyces cerevisiae, were characterized. The characterization of these gene products broadens previous knowledge about genetic studies on their role in $(1 \rightarrow 6)$ $\beta$-glucan biosynthesis (Roemer and Bussey, 1991). 


\section{B-glucan synthesis}

The enzymes endoglycosynthases help in synthesis of $\beta$ - glucan molecules through catalyzation of reactions that in turn catalyze the self-condensation of sugar donors for the in vitro synthesis of a regular polysaccharide. The specificity of the enzyme allowed the polymerization of $\alpha$-laminaribiosyl fluoride via the formation of $(1 \rightarrow 4)$ - $\beta$-linkages to yield a new linear crystalline $(1 \rightarrow 3)(1 \rightarrow 4)$ $\beta$-D-glucan with a repeating 4-glucose and 3glucose units (Magda et al., 2004). However, the mechanism may vary from species to species. Calcium promoted $\beta$-glucan synthase activity and promotion was also observed at free calcium concentrations (Paliyath and Poovaiah, 1988). Endo- $\beta-(1 \rightarrow 3)(1 \rightarrow 4)-$ glucanase is a thermo-stable enzyme and develops during the germination of barley; this is the major enzyme (Ahmad and Zaffar, $2014 \mathrm{~b}$ ). Associated with degradation of the $\beta$ glucan molecule after synthesis of $\beta$-glucan thereby controlling the length and the molecular weight of $\beta$-glucan in cereal crops (Ahmad et al., 2015a); Hrmova et al., 1997). While in microorganisms (in vivo) a different situation exists, the structure of $\beta$-glucan is engineered under strict control of genes. To understand this structural phe- nomenon, two genes, KRE6 and SKN1 of Sacchromyces cerevisiae, were characterized. The characterization of these gene products broadens previous knowledge about genetic studies on their role in $(1 \rightarrow 6)-\beta$-glucan biosynthesis (Roemer and Bussey, 1991). During synthesis of $\beta$-glucan from yeast KRE6 encodes a predicted type II membrane protein. SKN1 and KRE6 define a pair of functional homologs encoding putative membrane proteins involved in beta-glucan synthesis (Ahmad et al., 2015a). These genes are responsible for encoding of phosphorylation of membrane glycoproteins, and these genes reside in some part of the Golgi apparatus. Their role was more manifested when both of these genes were deleted as a result of disorganization in the cell wall ultrastructure (Roemer et al., 1993). Anothergene, PKC1, potentially participates in cell wall assembly by regulating the synthesis of cell wall components, including $(1 \rightarrow 6)-\beta$-glucan (Levin and BartlettHeubusch, 1992).

\section{Structure of $\beta$-glucan}

$\beta$-glucan is the predominant non-starch polysaccahride of cell walls in cereal grains such as barley and oats (Buckeridge et al., 2004; Wood, 1993; Izydorczyk et al.,2003). Structurally, cereal grains consist of long linear chains of glucose having $\beta-(1 \rightarrow 3)$ and $\beta$ - $(1 \rightarrow 4)$-linkages but these linkages are not arranged in a random and repeating fashion (Staudte, et al., 1983; Ayhan, 2005). However, $\beta$-glucan from baker's yeast has a different type of linkage; it consists of $\beta$ $(1 \rightarrow 3)$ as well as $(1 \rightarrow 6)$ linkages (Gardiner, 2004). In cereals, $\beta$-glucan $(1 \rightarrow 4)$ - linkages occur in groups of two to four while (1 3 )linkages occur singly. This leads to a structure that is dominated by $\beta-(1 \rightarrow 3)$-linked cellotriosyl and cellotetraosyl units (Woodward, et al., 1983; Wood et al., 1994; Wood, 2001). The rest of the structure consists of longer blocks of 4- 15 (14)-linked $\beta$-D- glucopyranosyl units (Wood et al., 1994). The structure of $\beta$-glucan resembles that of cellulose, the only difference being that the $\beta-(1 \rightarrow 3)$ - linkages establish a twist in the chain. This twist phenomenon gives stability to $\beta$-glucan and lessens its affinity to form aggregates, thus the solubility of $\beta$ glucan is greatly affected by such a trend. A lot of investigations are still required to determine the rationale of $\beta$-glucan solubility and its inter- action with these linkages. However, some previous research predicts that longer sequences of $(1 \rightarrow 4)$-linkages give less soluble $\beta$-glucans because of close intermolecular associations (Woodward et al., 
1983). However, Izawa et al., (1993) were of the view that $\beta$-(1 $\rightarrow 4)$-linkages had an insignificant influence on solubility as compared to that of long blocks of contiguous cellotriosyl residues. More recent data also holds up this assumption about structural regularity and gives an idea about how a high level of $\beta$ (13) linked cellotriosyl units reduces solubility and increases the tend encytogel (Bohme and Kulicke, 1999; Cui and Wood, $\overrightarrow{2000) .}$. On average, two or three $(1 \rightarrow 4)$-linked units exist and these are separated by a single $(1 \rightarrow 3)$-linkage in a molecule. However, there is still a chance of longer units linked through $(1 \rightarrow 4)$-linkages (Cui, et al., 2000; MacGregor and Rattan, 1993). Like $\beta$-glucan, the arabinoxylans also have a backbone of (1 4)-linked $\beta$ D-xylopyranosyl units. Some of these may substitute at position 2 and/or 3 with a Lbarley kernel it may present in the amounts of 3-11\% (Hanand Schwarz, 1996; Jadhav et al., 1998; Lehtonen and Aikasalo, 1987). The action of lichenase release, the main structural repeating units of $\beta$-D-glucans, as $3-O-\beta$-Dcellobiosyl- Dglucose (trisaccharide unit) and 3- $O$ - $\beta$-D-cellotriosyl-D- glucose (tetrasaccharide unit). The property of water solubility is attributed to the introduction of $(1 \rightarrow 3$ )-linkages in a cellulosic chain (Irakli et al., 2004). The degree of branching is negatively correlated with a rabinoxylans (AX) and, similar negative cor- relation found between $\beta$-glucan and arabinoxylan contents; whereas, a strong positive correlation also exists between $\beta$ - glucan and the amount of soluble non-starch polysaccharides (NSP) and protein contents was reported by Holtekjølen et al., (2006). Higher amounts of $\beta$-glucan have also been reported in waxy and the high amylose genotypes as compared to the normal genotypes (Anker-Nilsenn et al., 2006).

\section{Extraction of $\beta$-glucan}

A range of extraction and purification techniques are available for extraction of $\beta$ - glucan (Ahmad et al., 2015a). This may include hot water extraction (Smiderle et al., 2006; Ahmad et al., 2009), solvent extraction (Bhatty, 1993), enzymatic extraction (Irakli et al., 2004; Ahmad et al., 2010), and alkali extraction (Wei et al., 2006).

Indigenous enzymes may affect the recovery and properties of the extracted $\beta$-glucan. The major indigenous enzyme re- sponsible for hydrolyzing the $\beta$-glucan component in cereal is an endo- $\beta-(1 \rightarrow 3)(1 \rightarrow 4)$-glucanase, which develops during the germination of cereal crops (Hrmova et al., 1997). Several other enzymes such a send o-xylanases, a rabinofuranosidase, xy- loacetylesterase, and feruloyl esterase are also involved in the release of $\beta$-glucan from various sources. The relatively faster release of glucan was reported by two endo-xylanase preparations, although the most extensive release of glucan was obseved by an endo- $\beta$-glucanase. The latter released $90 \%$ of the glu- can above which was extracted by water alone (Kanauchil and Bamforth, 2001). Furthermore, two esterases were capable of extracting glucan to a more limited extent, one of them hy- drolyzing acetyl groups associated with xylan, the other breaking ferulic acid ester bonds. The latter are associated more with a rabinoxylan rather than $\beta$-glucan (Ahluwalia and Fry, 1986). However, this would not confound the argument that hydrolysis of a rabinoxylans enables the solubilization of $\beta$-glucan. These enzymes can be used alone but better results were observed when these enzymes were used in combination at various levels (Kanauchil and Bamforth, 2001). During the extraction process an appreciable amount of a rabinoxylan is also extracted along with $\beta$ glucan. The presence of a rabinoxylan may con- tribute hindrances in filtration, extraction, and add have during the brewing process (Jadhav et al., 1998; Mac Gregor and Rattan, 1993). These polysaccharides, if not extracted from animal feed, may pose some 
problems in such feed. The major draw back reported in animal feed is that it reduces the nutritive value of the feed. Other problems associated with these substances are sticky feces in poultry birds (Jadhav et al., 1998; MacGregor and Rattan, 1993; Svihus et al., 1995 (Ahmad, 2013a). Various extraction and purification techniques used for the extraction of $\beta$-glucan from the irrespective sources and the salient features of the extracted product are reviewed in Table 1.

\section{Molecular Weight of $\beta$-Glucan}

Size exclusion chromatography presents a better way to determine the molecular weight and size (radius of gyration) of $\beta$-glucan and like polysaccharides (Lazaridou et al., 2003). This technique is used in combination with various detectors such as refractive index detection (HPSEC-RI), multi-angle laser light scattering (MALLS), or with right angle light scattering com- bined with or without a viscosity (HPSEC-RI-RALLS-Visc) detector (Wei et al., 2006; Irakli etal., 2004). (Ahmad et al., 2014d) These detectors may be used alone or in combination with each other. Researchers had also used light scattering techniques to determine molecular weights and mean square radius without employing reference standards (Wyatt, 1993). Some researchers have preferred the use of refractive index detector to determine the molecular weight (Jackson and Barth, 1995). Light scattering from multiple angles (MALLS) is another option that can be used to determine the average molecular weight. RI-Visc measures the intrinsic viscosity, and this is used in situations where the concentration of the test material is low (White, 1999). On the other hand, SEC-RIMALLS use is confined for the average molecular weight. In size exclusion chromatography, it is assumed that each slice of a chromate gram contains molecules of a very narrow molecular weight distribution
(Irakli et al., 2004). Polysaccharides in cell walls consist of varying chain length and molecular weight. In such molecules the polydispersity can be calculated from the ratio of average molecular size to number average molecular weight. The average molecular weight is in- fluenced by the presence of size of the larger molecules, while the number of the average molecular weight is strongly influenced by the presence of small molecules. For a monodisperse polymer, the average molecular weight equals number average molecular weight giving a polydispersity of 1 , all molecules thus having identical molecular weights (Cuiand Wood, 2000; Wei et al., 2006). The calcoflour method is another procedure used to determine molecular weight of $\beta$-glucan. This process works on specific binding of Calcofluorto polysaccharide thus forming a glucan-Calcofluor complex that results in increased influorescence intensity and can be detected by a fluorescence detector (Trogh, et al., 2004; Wood, 1980). Such binding results in an increase influorescence intensity that is proportional to the concentration of $\beta$-glucan in solutions. This technique was initially employed to quantify $\beta$-glucan (Wood and Weisz, 1984; Mekis et al., 1987; Jørgensen, 1988) but today this technique along with size-exclusion chromatography (SEC) is used for molecular weight determination of $\beta$ glucan.Table2illustrates a brief review of various techniques used for molecular weight.

\section{Glucan-Binding Protein}

The glucan-binding proteins (GBPs) are a heterogeneous group of proteins with variations in size, glucan-binding do- main, glucan binding affinity, distribution and most importantly, function. These proteins are grouped together on the basis of their glucanbinding properties (Banas and Vickerman, 2003). These are surface proteins and bind with the surface receptor after pattern 
recognition (Pauchet et al., 2009) and the molecular weight for this $\beta$-glucan-receptor protein complex is approxi- mately $240 \mathrm{k} \mathrm{Da}$ and it contains another important $75 \mathrm{kDa}$ protein species form a king strong complex (Mithofer et al., 1996; Frey et al., 1993). This 75-kDa protein was isolated and characterized as a high-affinity binding protein (Umemoto et al., 1997; Mithofer et al., 1996). Some of the enzymes are also associated with glucanbinding proteins. These enzymes catalyze the synthesis of the glucans. Furthermore, these enzymes also hydrolyze the glucans molecules along with starch and cellulose, which ultimately act as substrates for microbial growth (Warren, 1996). Some of the $\beta$-glucan-binding protein (GBP) has a capacity to hydrolyze $\beta$ - (13) linkages in $\beta$ glucan (Fliegmann et al., 2004). These glucan binding proteins play a major role during various processes such as dextranase inhibition, dextran- dependent aggregation, plaque cohesion (Banas and Vickerman, 2003), pathogen defense, metabolism, polysaccharide biosynthesis, and virulence (Guillen et al., 2010). Recent studies indicated evidence that glucan-binding proteins amend virulence and sometime play a protective role by acting as immunogens in animal models (Ahmad et al., 2013d; Banas and Vickerman, 2003). The $\beta$-glucan binding protein (GBP) extracted from soybean (Glycine max L.) perform two major roles. First, it acts as are captor complex within the plasma membrane upon the binding and acts as mi- crobial cell wall elicit or and triggers the cascade of reaction that resulted in activation of defense responses. The second important function of these GBP is to hydrolyze $\beta$ - (1 3) -glucans that are present in the cell walls of pathogens (Fliegmann et al., 2005).

\section{Rheological properties of $\beta$-glucan}

The viscosity properties of $\beta$-glucan and other polysaccharides depend upon concentration of dietary fiber, their solubility, and molecular weight (MW) (AACC, 2001; Wood et al., $1991 ; 2000)$. There are numerous factors that affect viscosities in products with added $\beta$ glucan. According to Aastrup (1979) changes in viscosity of barley flours lurries originate due to the presence of endogenous enzymes. Two endogenous $\beta$-(13) (1 4)-D-glucan 4glucanohydrolase isoenzymes are responsible for the degradation of barley $\beta$-glucans (Woodward et al., 1983). The major enzyme involved in hydrolyzing the $\beta$-glucan component of barley is an endo- $\beta$ - (1 4) glucanase, which develops during the germination of barley (Hrmova et al., 1997). $\beta$-glucanases in cereals became in activated by a combination of heat $\left(90^{\circ} \mathrm{C}\right)$ and ethanol treatments for two hours and this had a pronounced stabilizing effect on the viscosity. A previous study has shown that heat treatment also has a capability of stabilizing the viscosity profile of flour slurries (Izydorczyk et al., 2000). According to Wei et $a l$., (2006) the melting temperature of wheat $\beta$-D-glucan gels increased with the increase of molecular weight. Initially, viscosities of the $\beta$-glucan containing solutions tend to increase due to initial solubilization of the $\beta$-glucans, but no detectable decline has been observed there after. Addition of low purity $\beta$-glucan to the medium molecular weight starch significantly increases the viscosity of solution when determined at low shear rates (Faraj et al., 2006). Fluid dynamic parameters also influence the flow, diffusion, or transport behavior of $\beta$-glucan during digestion in the small intestine, but the influence of the viscous behavior is limited. The rheological behavior of $\beta$-glucan was studied in the past by using oscillatory and rheological measurement. The predominant viscous behavior was explained on the basis of storage and loss moduli Gr and Grr of $\beta$ glucan preparations from extruded meal and bran that tends to increase continuously with increasing frequency (Dongowski et al., 
2005). In freshly prepared barley $\beta$-glucan solutions, attraction forces between molecules are less strong but after an induction period some $\beta$-glucan solutions/dispersions may begin to adopt gel-like behavior (Bohme and Kulicke, 1999). She arthinning behavior of cereal $\beta$-glucans was also exhibited at low concentration, but at higher concentration they tend to form gels and their gelling properties are influenced by molecular weights and molecular structure (Cui, 2001; Lazaridou et al., 2003; 2004; Lazaridou and Biliaderis, 2004). Higher molecular weight (2.39 105) $\beta$-glucan gel did not show any tendency to gel even after 200hours storage. On the other hand, short chain molecules with low molecular weight show higher mobility and these short chains with low molecular weight $\beta$-glucan structures diffuse more readily, and hence have a greater possibility of forming junctions with neighboring chains (Doublier and Wood, 1995). This evidence indicates that there is an inverse relationship between gelation time and molecular weight of the polysaccharide (Lazaridou et al., 2003; Vaikousi et al., 2004). Viscosity properties are also influenced by tri/tetra ratios, cellulose-like fragments, molecular weight distribution, and molecular size of cereal $\beta$ glucan. Furthermore, they have a capacity to alter some other physiological responses when they are intended to be used in cereal based products (Izydorczyk and Biliaderis, 2000; Vaikousi et al., 2004).

\section{Health implication of $\beta$-glucan}

A large number of studies indicated the effectiveness of $\beta$ - glucan against various diseases and disorders, and several applications reported in previous scientific work are the tendency to reduce onset of colorectal cancer (Dongowski et al., 2002), increased stool bulk and provide assistance against constipation (Odes et al., 1993; ValleJones, 1985), reduction in glycemic index (Cavallero et al., 2002; Jenkins et al., 2002;
Granfeldt et al., 2008), flattening of the postprandial blood glucose levels and insulin rises (Hallfrisch et al., 2003; Li et al., 2003; Jenkins et al., 2002), prevention of insulin resistance (Brennan and Cleary, 2007; Hlebowicz et al., 2008), reduction in serum cholesterol levels (Delaney et al., 2003; Kang, et al., 2003; Kerckhoffs et al., 2003; Li et al., 2003; Yang et al., 2003; Smithetal., 2004), prevention of coronary heart disease (Jinshui et al., 2002), production of short chain fatty acids (Wisker et al., 2000), prevention of hepatic damage by reducing taxol induced hepatic damage (Ahmad et al., 2015b) Karaduman et al., 2010), and promotion of the growth of beneficial gut microflora (Crittenden et al., 2002; Tungland, 2003).

Viscous fibers are responsible for beneficial physiological responses in human, animal, and animal-alternative in vitro models (Cheryl et al., 2006). These responses are altered primarily by $\beta$-glucan, but a rabinoxyl an may also influence these changes since both types of fiber have a tendency to increase viscosity in solutions (Newman and Newman, 1992). There is evidence indicating that $\beta$-glucan and other dietary fibers have protective roles to play in preventing or delaying the onset of chronicdis- eases and disorders such as coronary heart disease (Liu et al., 2000; Truswell, 2002), diabetes mellitus, cancer, and colondys function (Meyer et al., 2000; Sudha et al., 2007). Tungland and Meyer (2003) also reviewed a range of dietary fiber including $\beta$-glucan with reference to beneficial physiological influences that they exert on the human body. To achieve these physiological responses $3 \mathrm{~g}$ soluble fiber consumption daily may lower the total cholesterol by 0.41 mmolL-1 in hypercholesterolemic persons and 0.13 mmolL -1 in normocholesterolemic persons (Kerckhoffs et al., 2003). Similarly, Behall et al., (1997) reported that ingestion of $2.1 \mathrm{~g}$ of $\beta$-glucanona daily basis reduces total cholesterol by $9.5 \%$, where as some findings 
by some researchers (Jenkins et al., 2002) indicated that 4 units decline in glycemic index can be achieved by taking $1 \mathrm{~g}$ of $\beta$ glucan per $50 \mathrm{~g}$ of carbohydrates. FDA has also recommended a daily consumption of $3 \mathrm{~g}$ $\beta$-glucan to achieve such health benefits (FDA, 1997). In a comparison study to evaluate the effect of oat bran and oat meal (same quantity) on reduction of LDLcholesterol, oat bran was found to have a greater capability over oat meal to reduce LDL-cholesterol levels (Davidson et al., 1991). As concerned with source of $\beta$-glucan, barley $\beta$-glucan was more effective in the regulation of glucose and insulin responses compared too at $\beta$-glucan (Hallfrisch and Behall, 2000; Yokoyama et al., 1997; Hallfrisch et al., 2003; Granfeldt et al., 2008). Regarding the cholesterol lowering mechanism and binding of bile acid, it was noticed that $\beta$-glucan containing extrudates from oat have an ability to bind bile acid and to replenish the deficiency of bile acid, more cholesterol from the body is consumed for the synthesis of bile acid thus lowering the serum cholesterol level in the body (Drzikova et al., 2005). Higher bile acid binding capacity in oat $\beta$-glucan can be achieved by amination (Liu et al., 2010) and oxidation (Park et al., 2009) thus help in the removal of more cholesterol due to the introduction of cat ionic groups into the $\beta$-glucan molecules (Shin et al., 2005; Liu et al., 2010).

Apart from cereal grains such as barley, oats, rye, certain fungi containing $\beta$-D-glucan have a capacity to reduce total blood (Ahmad et al., 2013 c) cholesterol level with in the body (Genc et al., 2001; Ozdemir and Genc, 2001). Oat extract diets are considered to lower the total and LDL cholesterol levels, and a significant difference with respect to lowering of cholesterol was also observed within both high oat and low oat containing diets. This difference was attributed due to difference in $\beta$-glucan contents in the diets (Behall et al.,
1997).

Consumption of a diet high in barley $\beta$-glucan has been shown to prevent insulin resistance and can be used for diabetic patients (Ostman et al., 2006; Brennan and Cleary, 2007; Hlebowicz et al., 2008). The beta glucan containing diet promoted hepatic insulin signaling by decreasing serine phosphorylation of insulin receptor (Choi et al., 2010). In are cent study, Beck et al., (2009) observed decrease in insulin response and increased post prandial cholecystokinin levels after ingestion of $\beta$-glucan in over weight human subjects. Gran field total. (2008) suggested intake of 4 goat $\beta$-glucans to achieve significant decrease in glucose and insulin responses in healthy subjects thus favoring the diabetic patients. Several researchers advocated the need for reevaluation of the quantity, the food vectors, and the tolerability of $\beta$-glucan products to improve the metabolic profile of type 2 diabetic subjects in the long term (CugnetAnceau et al., 2010).

\section{Application of $\beta$-glucans in food products}

Apart from health and nutritional benefits (Malkkiand Virtanen, 2001), $\beta$-glucan also has various suitable functional properties such as thickening, stabilizing, emulsification, and gelation. These properties determine the suitability of $\beta$-glucan to be incorporated in soups, sauces, beverages, and in other food products (Dawkins and Nnanna, 1995;Burkus and Temelli, 2000). Barley $\beta$-glucan is particularly well suited for such applications, being capable of imparting a smooth mouth feel to beverage products, and also makes the beverage an excellent source of soluble dietary fiber. Its properties enable it to be incorporated alternatively in traditional beverage thickeners as replacement forgum Arabic, alginates, pectin, xanthangum, and arboxymethyl-cellulose (Giese, 1992). 
Table.1 Avena species - genome constitution and chromosome number

\begin{tabular}{|c|c|c|}
\hline Classification & Chromosome no. & Genome constitution \\
\hline \multicolumn{3}{|c|}{ Section Avenotrichon } \\
\hline A.macrostachya & $4 x=28$ & \\
\hline \multicolumn{3}{|c|}{ Section ventricosa } \\
\hline A.clauda & $2 x=14$ & $\mathrm{C}_{\mathrm{P}} \mathrm{C}_{\mathrm{P}}$ \\
\hline A.eriantha & $2 x=14$ & $\mathrm{C}_{\mathrm{P}} \mathrm{C}_{\mathrm{P}}$ \\
\hline A.ventricosa & $2 x=14$ & $\mathrm{C}_{\mathrm{v}} \mathrm{C}_{\mathrm{v}}$ \\
\hline \multicolumn{3}{|l|}{ Section Agraria } \\
\hline A.brevis & $2 x=14$ & $\mathrm{AA}$ \\
\hline A. Hispanica & $2 x=14$ & $\mathrm{AA}$ \\
\hline A. nuda & $2 x=14$ & $\mathrm{AA}$ \\
\hline A. strygosa & $2 x=14$ & AsAs \\
\hline \multicolumn{3}{|c|}{ Section Tenaicarpa } \\
\hline \multicolumn{3}{|c|}{ A. agadiriana } \\
\hline A. atlantica & $2 x=14$ & AsAs \\
\hline A. barbata & $4 x=28$ & $\mathrm{AABB}$ \\
\hline A. canariensis & $2 x=14$ & AcAc \\
\hline A.damascena & $2 x=14$ & AdAd \\
\hline A. hirtula & $2 x=14$ & AsAs \\
\hline A.longiglumis & $2 x=14$ & $\mathrm{AiAi}$ \\
\hline A.lusitanica & $2 x=14$ & AA \\
\hline A.matritensis & $2 x=14$ & \\
\hline A.prostrata & $2 x=14$ & $\mathrm{~A}_{\mathrm{P}} \mathrm{A}_{\mathrm{P}}$ \\
\hline A.wiestii & $2 x=14$ & AsAs \\
\hline \multicolumn{3}{|l|}{ Section Ethiopica } \\
\hline A.abyssinica & $4 x=28$ & $\mathrm{AABB}$ \\
\hline A.vaviloviana & $4 x=28$ & $\mathrm{AABB}$ \\
\hline \multicolumn{3}{|c|}{ Section Pachycarpa } \\
\hline A.moroccana & $4 x=28$ & $\mathrm{AACC}$ \\
\hline A.murphyi & $4 x=28$ & $\mathrm{AACC}$ \\
\hline \multicolumn{3}{|l|}{ Section Avena } \\
\hline A. atherantha & $6 x=42$ & AACCDD \\
\hline A. fatua & $6 x=42$ & AACCDD \\
\hline A. hybrid & $6 x=42$ & AACCDD \\
\hline A. occidentalis & $6 x=42$ & AACCDD \\
\hline A. sativa & $6 x=42$ & AACCDD \\
\hline A. sterilis & $6 x=42$ & AACCDD \\
\hline A. trichophylla & $6 x=42$ & AACCDD \\
\hline
\end{tabular}


Table.2 Extraction of beta glucan bv different methods

\begin{tabular}{lll}
\hline$\beta$-glucans $(\mathrm{g} / 100 \mathrm{~g}$ & Method & Reference \\
\hline $10.9-1.0^{\mathrm{b}}$ & Enzymic & Lamboet al., \\
$4.0 \pm 0.1^{\mathrm{a}}$ & enzymic + HPAEC- & (2005) Johansson \\
$4.1 \pm 0.19^{\mathrm{a}}$ & PAD Enzymic & et al., (2004) \\
$10.37 \mathrm{~b}$ & Enzymic & Gencet al., (2001) \\
$2.47-3.45^{\mathrm{a}}$ & alkaline extraction & Dongowskiet al., \\
$1.73-5.7^{\mathrm{a}}$ & Enzymic & Weightmanet al., \\
$13.79-33.73 \mathrm{~b}$ & enzymatic-gravimetric & Gajdošova (2007) \\
Beta-glucan $\%$ & & \\
& & Havrlentova and Kraic \\
$3.77-8.56($ Parents $)$ & Enzymic & Ahmad and Zaffar \\
& Enzymic & Ahmad et al., (2015c) \\
$3.98-10.23$ (F1s) & & \\
chromatography & with pulsed amperometric detection
\end{tabular}

\section{CROSSING PROGRAMME}

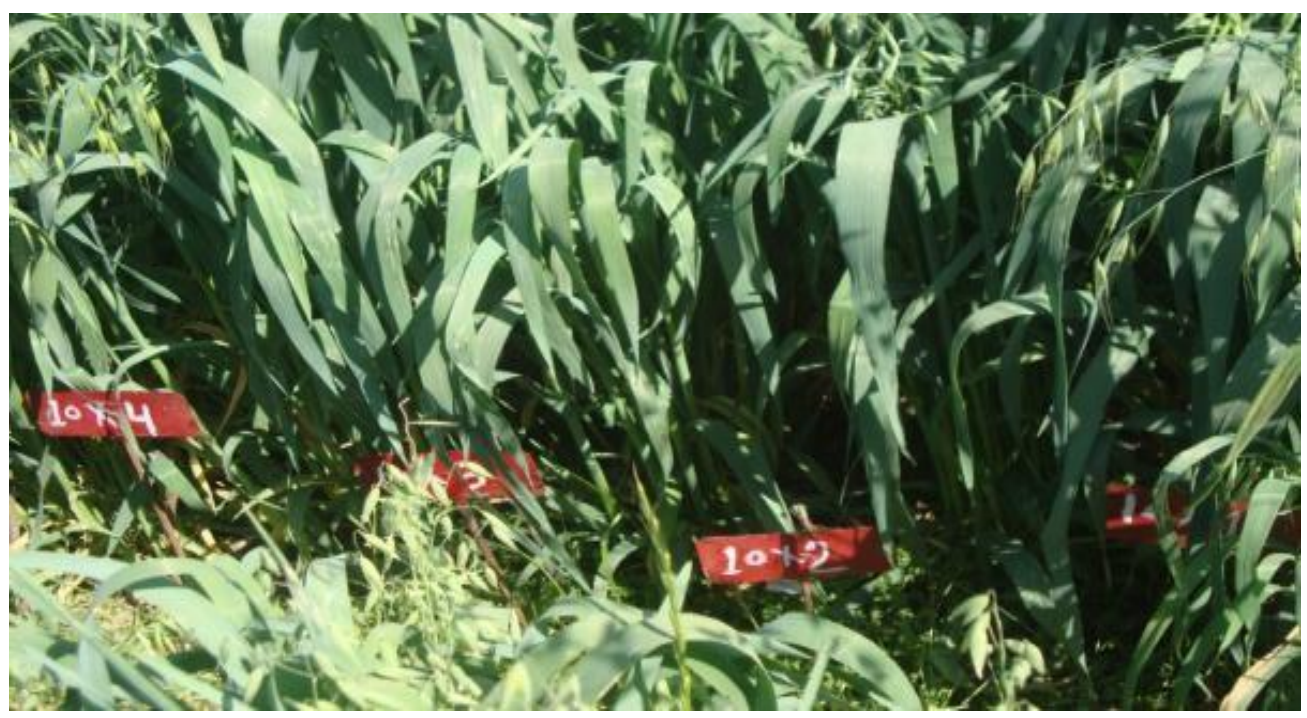


Table.3 Fibre content in different oat-based food products

\begin{tabular}{|c|c|c|c|}
\hline \multirow{8}{*}{ Oats } & Food & Soluble $\beta$-glucanss & Reference \\
\hline & \multirow[t]{2}{*}{ whole meal } & 2.66 & Gajdošova (2007) \\
\hline & & 4.51 & $\begin{array}{l}\text { Grausgruber } \text { et al., } \\
(2004)\end{array}$ \\
\hline & \multirow[t]{2}{*}{ Groat } & 3.16 & Gajdošova (2007) \\
\hline & & $3.5-5.0$ & $\begin{array}{l}\text { Malkki and Virtanen } \\
(2001)\end{array}$ \\
\hline & \multirow{2}{*}{$\begin{array}{l}\text { bran } \\
\text { concentrate }\end{array}$} & 7.48 & Gajdošova (2007) \\
\hline & & $11.5-17.0$ & \multirow{2}{*}{$\begin{array}{l}\text { Malkki and Virtanen } \\
(2001) \\
\text { Havrlentova and } \\
\text { Kraic (2006) }\end{array}$} \\
\hline & Flakes & $2.64-4.6$ & \\
\hline
\end{tabular}

Table.3 Fibre content in different oat-based food products

\begin{tabular}{llll}
\hline & Food products & Soluble $\beta$-glucanss $(\mathrm{g} / 100 \mathrm{~g}$ dry & Reference \\
\cline { 2 - 4 } Oats & 2.66 & Gajdošova (2007) \\
& & 4.51 & Grausgruberet al., (2004) \\
& Groat & 3.16 & Gajdošova (2007) \\
& & $3.5-5.0$ & Malkki and Virtanen (2001) \\
& bran concentrate & 7.48 & Gajdošova (2007) \\
& $11.5-17.0$ & Malkki and Virtanen (2001) \\
& Flakes & $2.64-4.6$ & Havrlentova and Kraic (2006) \\
\hline
\end{tabular}

Table.4 Oats nutritional value per 100 grams

\begin{tabular}{llll}
\hline Vitamin C & $0 \mathrm{mg}$ & Tryptophan & $0.234 \mathrm{~g}$ \\
Thiamin & 0.763 & Threonine & $0.575 \mathrm{~g}$ \\
Riboflavin & 0.139 & Isoleucine & $0.694 \mathrm{~g}$ \\
Niacin & 0.961 & Leucine & $1.284 \mathrm{~g}$ \\
Pantothenic & 1.349 & Lvsine & $0.701 \mathrm{~g}$ \\
Vitamin B-6 & 0.119 & Methionine & $0.312 \mathrm{~g}$ \\
Total folate & $56 \mathrm{mcg}$ & Cvstine & $0.408 \mathrm{~g}$ \\
Vitamin B- & 0 mcg & Phenvlalani & $0.985 \mathrm{~g}$ \\
Vitamin A & $0 \mathrm{IU}$ & Tvrosine & $0.573 \mathrm{~g}$ \\
Retinol & $0 \mathrm{mcg}$ & Valine & $0.937 \mathrm{~g}$ \\
& & Arginine & $1.192 \mathrm{~g}$ \\
& & Histidine & $0.405 \mathrm{~g}$ \\
& & Alanine & $0.881 \mathrm{~g}$ \\
& & Aspartic & $1.448 \mathrm{~g}$ \\
& & Glutamic & $3.712 \mathrm{~g}$ \\
& & Glvcine & $0.841 \mathrm{~g}$ \\
& & Proline & $0.934 \mathrm{~g}$ \\
& & Serine & $0.750 \mathrm{~g}$ \\
\hline
\end{tabular}

Data source: USDA National Nutrient Database 
Previous and recent research is focused to explore the ways to incorporate $\beta$-glucans into various food systems (Hallfrisch and Behall, 1997; Ahmad et al., 2008). In this context, $\beta$ glucan is extracted from different sources and marketed in various forms such as $\beta$-glucan concentrate extracted from oats ("Oattrime"), $\beta$-glucan from barley ("Nutrim Xe") and $\beta$ glucan extracted from rice ("Ricetrim") (Inglett et al., 2004).

Arabinoxyan and $\beta$ glucan when incorporated into flour for preparation of bread (Trogh et al., 2004; Ahmad et al., 2008), this addition not only markedly improved the loaf volume of bread (Ahmad and Zaffar, 2014a), but also increased the soluble fiber (Trogh et al., 2004) and firmness of the bread crumb (Lazaridou et al., 2007). Addition of $\beta$-glucan from barley and oat sources was recently reported by Kalinga and Mishra (2010) with promising rheological and physical properties of cake batter. In another attempt, enrichment of bread (at 2.5 and 5\%) using purified barley $\beta$-glucan fractions was evaluated for in vitro digestion process. This resulted in significant reduction in starch breakdown and this degradation is proportional to the amount of $\beta$-glucan incorporated into the breads (Symons and Brennan, 2004). High-fiber diets and foods with low glycemic index may act a sprophylactic against prevention and treatment of coronary heart diseases and diabetes (Jinshui et al., 2002; Granfeldt et al., 2008). Incorporation of $\beta$-glucan into pasta products revealed a lower glycemic response (Yokoyama et al., 1997). Similarly, a reduced glycemic index was reported in $\beta$-glucanen riched breakfast bar (Jenkins et al., 2002) and $\beta$-glucan containing bread (Cavallero et al., 2002). $\beta$-glucan has various applications in the food process industry including the bread and baking industry as thicken- ing agents for increasing viscosity, fat substitutes, as sources of dietary fiber, and for improvement of rheological properties (Ahmad et al., 2008;
2010; Andersson et al., 2009). Wheat flour, which is a poor source of dietary fiber (Dziezak, 1987) can be fortified by incorporating $\beta$-glucan for preparation of bread and other products (Ahmad et al., 2015b; Trogh et al., 2004). This incorporation of $\beta$-glucan in breads have a capacity to slow down the release of reducing sugars (in vitro) and consequently, increase the starch availability for digestion ultimately reduce the hyperglycemic and hyper insulinemic conditions (Brennan and Cleary, 2007; Thondre and Henry, 2009). This inclusion of $\beta$-glucan also improves the bread physiochemical characteristics (Cavallero et al., 2002), viscoelastic (Skendi et al., 2010), rheological and sensory properties (Flander $e t$ al., 2007; Skendi et al., 2010). There are controversial results for loaf volume; incorporation of $\beta$-glucan reduce the loaf volume (Rudel, 1990) by binding of large amounts of water so that limited amounts of water was available for the development of the gluten network and hence reduced loaf volume and tough textures was reported (Pomeranz et al., 1977). On the contrary, Yun-Hyoung et al., (2006) showed an improvement in loaf volume, and the textural and sensory properties of milky bread by incorporation of $\beta$-glucan. Enzymatic degradation of $\beta$-glucan during process-ing is a common problem during bread preparation (Cavallero et al., 2002; Moriartey et al., 2010) but it can be avoided by the use of coarse flour thereby providing protection to $\beta$-glucan from enzymatic degradation (Flander et al., 2007). The use of $\beta$-glucan is not only confined to cereal based products but its incorporation was also evaluated in beverages (Lyly et al., 2003; Temelli et al., 2004) and dairy based products (Konuklar et al., 2004), it can also find some applications in the manufacture of low-fat ice creams and yogurts (Brennan et al., 2002) and it can also be incorporated in combination with other soluble dietary fiber into low fat dairy 
products and low fat cheese curds to improve gelation and rheological characteristics (Tudorica et al., 2004). The incorporation of barley $\beta$-glucan in combination with whey protein into food products may help in the enrichment of the diet and assist in the prevention of certain diseases (Temelli et al., 2004). More- over, better soups can be prepared with a reasonable amount of $\beta$ glucan (Lyly et al., 2004; 2007). Ricetrim is another type of soluble $\beta$-glucan fiber extracted from rice and is used as fat replacer with a smooth mouth feel and texture. It is successfully used in cookies, pumpkin pudding, layer cake, dipforpot crust, taro custard, and sauté chicken curry (Inglett et al., 2004).

In conclusion $\beta$-glucan is a valuable functional ingredient that can provide a better physiological response and have several health promoting applications. Its promising physiochemical characteristics favor its use in various food systems. Extraction conditions of- ten affect the quality, quantity, molecular weight, viscosities, and other physiochemical properties of $\beta$-glucan. Therefore, future are search should focus on developing and characterization of new extraction technologies. To achieve complete benefits of this important functional ingredient, it is imperative that future research should be aimed at utilization of $\beta$-glucan for the development of new products. Unexplored areas about health application need special attention. Similarly, more research is required to understand the mechanism by which $\beta$ glucan enhances the immune system.

\section{References}

AACC (2001). AACC Dietary Fiber Technical Committee. The definition of dietary fiber. Cereal Foods World. 46: 112-126.

Aastrup, S. (1979). The effect of rain on $\beta$-glucan content in barley grains. Carlsberg Research Communications. 44: 381-393.

Ahluwalia, B. and Fry, S. C. (1986). Barley endosperm cell walls contain a feruloylated arabinoxylan and a non-feruloylated $\beta$-glucan. J. Cereal Sci. 4 : 287-295.

Ahmad M., and Zaffar, G. (2014a). Beta- glucan and Grain protein studies of oats (Avena sativa L.) under temperate conditions. Electronic Journal of Plant breeding. 6(1): 355-359.

Ahmad M., and Zaffar, G. (2014b). Study of heterosis, inter-relationship and path analysis of green fodder yield and its contributing traits in oats (Avena sativa L.). Research Journal of Agriculture Sciences. 5(2):235-241.

Ahmad. M., Zaffar, G., Zeerak, N.A., Dar, Z.A,.Mir, S.D., and Rather, M.A. (2010a). Explotitation of genetic variability in oats germplasm for harnessing higher fodder productivity. Range management and Agro forestry issue B; pp153154.

Ahmad. M., Zaffar, G., Mir, S.D., Dar, Z.A., Razvi, S.M., Iqbal, S., andHabib, M. (2014c). Genetic analysis for fodder yield and its important traits in oats (Avena sativa L.).Indian Journal of Genetics and Plant Breeding. 74(1):112-114

Ahmad. M., and Zaffar, G. (2014d). Heterosis Expression, Correlation and Path Analysis Studies of Grain Yield and its Contributing Traits in Oats (Avena sativa L.) Research Journal of Agriculture Sciences. 5(2):264-268.

Ahmad. M., Zaffar, G., Razvi S.M., Dar Z.A. (2015a). Genetic analysis for beta glucan, grain protein and other important traits in oats (Avena sativa L.).Indian Journal of Genetics and Plant Breeding. 75(1):136-139.

Ahmad., M, Zaffar G., Razvi S.M., Dar Z.A., Khan M.H. and Ganie S.A. (2013b). Combining ability study in oat (Avena sativa L.) for physiological, quality traits, forage and grain yield. African Journal of Agriculture Research, 8(43): 52455250 .

Ahmad., M., Gul-Zaffar, B.A. Wani, Uzma Mehraj, Z.A. Dar, Ajaz A Lone, M.A. Rather (2016a). Genotype $\mathrm{x}$ environmental interaction and stability analysis for grain quality and yield in oats (Avena sativa L.). Electronic Journal of Plant breeding.7(4): 1132- 1135.

Ahmad., M., Zaffar G., Mehraj U., JehangirIA., LoneAA. (2015b). Stability analysis for forge quality traits in Oats (Avena sativa L.) over environments. International Journal of Science and Nature. 6(4); 590-595

Ahmad., M., Zaffar G., Mir SD., Dar ZA., Dar SH., Iqbal S., Bukkhari SA., Khan GH., Gazal A (2013c) Estimation of correlation coefficient in oats (Avena sativa L.) for forage yield, grain yield and their contributing traits. International Journal of Plant Breeding and Genetics. Pp. 1-4 
Ahmad., M., Zaffar G., Razvi SM., Mir SD and Rather MA. (2013d). Stability properties of certain oats genotypes for major grain yielding

Ahmad, A., Anjum, F. M., Zahoor, T., Chatha, Z. A., Ahmad M and Nawaz, H. (2008). Effect of barley $\beta$-glucan on sensory characteristics of bread. Pak. J. Agric. Sci. 45(1): 88-94.

Ahmad, A., Anjum, F. M., Zahoor, T., Nawaz, H., and Din, A. Ahmad M (2009). Physico- chemical and functional properties of barley $\beta$-glucan as affected by different extraction procedures. Int. J. Food Sci. and Tech. 44: 181-187.

Ahmad, A., Anjum, F. M., Zahoor, T., Nawaz, H., and Ahmed, Z. (2010). Ex- traction and characterization of $\beta$-d-glucan from oat for industrial utilization. Int. J. Biological Macromolecules. 46(3): 304-309.

Akihiro, K., Fumihisa, K., Godliving, M., and Yoshitoshi, N. (2006). Develop- ment of optimal culture method of Sparassis crispa mycelia and a new extrac- tion method of antineoplastic constituent. Biochem. Eng. J. 30(1): 109-113.

Åman, P., Lena, R., and Roger, A. (2004). Molecular weight distribution of beta-Glucan in oat-based foods. Cereal Chem. 81(3): 356-360.

Andersson, R., Fransson, G., Tietjen, M., Aman, P. (2009). Content and molecular-weight distribution of dietary fiber components in whole-grain rye flour and bread. J. Agric. Food Chem. 57(5): 2004-2008.

Anker-Nilssen, K., Færgestad, E. M., Sahlstrøm, S., and Uhlen, A. K. (2006). Interaction between barley cultivars and growth temperature on starch degra- dation properties measured in vitro. Animal Feed Sci. and Tech. 130(1-2): 3-22.

Ayhan, D. (2005). $\beta$-Glucan and mineral nutrient contents of cereals grown in Turkey. Food Chem. 90(4): 773-777.

Banas, J. A. and Vickerman, M. M. (2003). Glucanbinding proteins of the oral streptococci. Crit. Rev. Oral Biol Med. 14(2): 89-99.

Beck, E. J., Tosh, S. M., Batterham, M. J., Tapsell, L. C., and Huang, X. F. (2009). Oat beta-glucan increases postprandial cholecystokinin levels, decreases insulin response and extends subjective satiety in overweight subjects. Mol Nutr Food Res. 53(10): 1343-1351.

Behall, K. M., Schofield, D. J., and Hallfrisch, J. (1997). Effect of beta glucan level in oat fiber extracts on blood lipids in men and women. $J$. of the American College of Nutr. 16: 46-51.

Bhatty, R. S. (1993). $\beta$-glucan content and viscosities of barleys and their roller milled flour and bran products. Cereal Chem. 69: 469-471.

Bhatty, R. S. (1995). Laboratory and pilot plant extraction and purification of $\beta$-glucans from hull-less barley and oat brans. J. of Cereal Sci. 22(2): 163-167.

Bo“hme, N. and Kulicke, W. M. (1999). Rheological studies of barley (1 3)(1 4)- $\beta$-glucan in concentrated solution: Investigation of the viscoelastic flow behavior in the sol-state. Carbohydr. Res. 315: 293-301.

Brennan, C. S. and Cleary, L. J. (2005). The potential use of cereal (1 3$)$ (1 4$)$ - $\beta$-D-glucan as functional food ingredients. J. of Cereal Sci. 42: $1-13$.

Brennan, C. S. and Cleary, L. J. (2007). Utilisation of Glucagel in the $\beta$-glucan enrichment of breads: A physicochemical and nutritional evaluation. Food Res. Int. 40(2): 291-296.

Brennan, C. S., Tudorica, C. M., and Kuri, V. (2002). Soluble and insoluble dietary fibers (non-starch polysaccharides) and their effects on food structure and nutrition. Food Ind. J. 5: 261-272.

Buckeridge, M. S., Rayon, C., Urbanowicz, B., Tine, M. A. S., and Carpita, N. C. (2004). Mixed linkage (1 3) (1 4) - $\beta$-D-glucans of grasses. Cereal Chem. 81: 115-127.

Burkus, Z. and Temelli, F. (2000). Stabilization of emulsions and foams using barley beta-glucan. Food Res. Int. 33: 27-33.

Codex Alimentarius Commission (CAC) (2006). Report of the 27th Session of the Codex Committee on Nutrition and Foods for Special Dietary Uses (CC- NFSDU), Bonn, Germany, 21-25 November, 2005. ALINORM 06/29/26, 2006.

Cao, W., Li, X. Q., Liu, L., Wang, M., Fan, H. T., Li, C., Lv, Z., Wang, X., and Mei, Q. (2006). Structural analysis of water-soluble glucans from the root of Angelica sinensis (Oliv.) Diels. Carbohydr Res. 14(11): 1870-1877.

Cavallero, A., Empilli, S., Brighenti, F., and Stanca, A. M. (2002). High (1 3,1 4)- $\beta$-glucan barley fractions in bread making and their effects on human glycemic response. J. Cereal Sci. 36: 5966.

Chakraborty, I., Mondal, S., Pramanik, M., Rout, D., and Islam, S. S. (2004). Structural investigation of a water-soluble glucan from an edible mushroom, Astraeus hygrometricus. Carbohydr. Res. 339(13): 2249- 2254.

Chakraborty, I., Mondal, S., Rout, D., and Islam, S. S. (2006). A water-insoluble (1 3)-beta-D-glucan from the alkaline extract of an edible mushroom Ter- mitomyces eurhizus. Carbohydr. Res. 341(18): 2990-2993.

Chauveau, C., Talaga, P., Wieruszeski, J. M., Strecker, G., and Chavant, L. (1996). A water-soluble beta-D-glucan from Boletus erythropus. Phytochem- istry. 43(2): 413-415. 
Cheryl, L., Dikeman, A., and Fahey, G. C. (2006). Viscosity as related to dietary fiber: A review. Critical Reviews in Food Science and Nutrition. 46: 649-663. Choi, J. S., Kim, H., Ho Jung, M., Hong, S., and Song, J. (2010). Consumption of barley $\beta$-glucan ameliorates fatty liver and insulin resistance in mice fed a high-fat diet. Molecular Nut. and Food Res. (In Press)

Cordeiro, L. M., Stocker-Worgotter, E., Gorin P. A., and Iacomini, M. (2003). Comparative studies of the polysaccharides from species of the genus Ramalina-lichenized fungi-of three distinct habitats. Phytochemistry. 63(8): 967-975.

Crittenden, R., Karppinen, S., Ojanen, S., Tenkanen, M., Fagerstrom, R., Matto, J., Saarela, M., Matiila-Sandholm, T., and Poutanen, K. (2002). In vitro fer- mentation of cereal dietary carbohydrates by probiotic and intestinal bacteria. of the Sci. of Food and Agric. 82: 781789.

DeVries, J. W. (2001). AACC report: The definition of dietary fiber. Cereal Foods World. 46(3): 112126.

Delaney, B., Nicolosi, R. J., Wilson, T. A., Carlson, T., Frazer, S., Zheng, G. H., Hess, R., Ostergren, K., Haworth, J., and Knutson, N. (2003). Betaglucan fractions from barley and oats are similarly antiatherogenic in hypercholesterolemic Syrian golden hamsters. J. of Nutr. 133: 468-475.

Dong, Q., Yao, J., Yang, X.T., and Fang, J. N. (2002). Structural characterization of a water-soluble $\beta$ D-glucan from fruiting bodies of Agaricus blazei Murr. Carbo. Res. 337(15): 1417-1421.

Dongowski, G., Drzikova, B., Senge, B., Blochwitz, R., Gebhardt, E., and Habel, A. (2005). Rheological behaviour of $\beta$-glucan preparations from oat products. Food Chem. 93(2): 279-291.

Dongowski, G., Huth, M., Gebhardt, E., and Flamme, W. (2002). Dietary fiber rich barley products beneficially affect the intestinal tract of rats. $J$. of Nutr. 132: 3704-3714.

Cugnet-Anceau, C., Nazare, J. A., Biorklund, M., Le Coquil, E., Sassolas, A., Sothier, M., Holm, J., Landin-Olsson, M., O* nning, G., Laville, M., and Moulin, P. (2010). A controlled study of consumption of $\beta$-glucan-enriched soups for 2 months by type 2 diabetic free-living subjects. Br. J. Nut. 103: 422-428.

Cui, S. W. (2001). Polysaccharides gums from agricultural products: Processing, structure and functionality. Lancaster Technomic. Lancaster, PA: Technomic Publishing Company Inc., 103166.

Cui, W. and Wood, P. J. (2000). Relationships between structural features, molecular weight and rheological properties of cereal b-D-glucans. In: Hy- drocolloids Physical Chemistry and Industrial Applications of Gels, Polysaccharides, and Proteins, Vol. 1., pp. 159-168, Nishinari, K., Ed., Elsevier, Amsterdam.

Cui, W., Wood, P. J., Blackwell, B., and Nikiforuk, J. (2000). Physicochemical properties and structural characterization by two-dimensional NMR spec- troscopy of wheat $\beta$-D-glucan comparison with other cereal $\beta$-D-glucans. Carbohydrate Polymers 41(3): 249-258.

Danie"lle, A. J., Kerckhoffs, M., Gerard, H., and Ronald, P. M. (2003). Cholesterol-lowering effect of $\beta$-glucan from oat bran in mildly hyperc- holesterolemic subjects may decrease when $\beta$-glucan is incorporated into bread and cookies. Am. J. Clin. Nutr. 78: 221-227.

Davidson, M. H., Dugan, L. D., Burns, J. H., Bova, J., Story, K., and Drennan, B. (1991). The hypocholesterolemic effects of beta-glucan in oatmeal and oat bran. A dose-controlled study. JAMA. 265(14): 234-237.

Dawkins, N. L. and Nnanna, I. A. (1995). Studies on oat gum (1 3,1 4)- $\beta$-d- glucan: Composition, molecular weight estimation and rheological properties. Food Hydrocoll. 9(1): 1-7.

De Paula, A. C., Sousa, R.V., Figueiredo-Ribeiro, R.C., and Buckeridge, M.S. (2005). Hypoglycemic activity of polysaccharide fractions containing beta- glucans from extracts of Rhynchelytrum repens (Willd.). J. Med. Biol. Res. 38(6): 885893.

Dervilly, G., Leclercq, C., Zimmermann, D., Roue, C., Thibault, J. F., and Saulnier, L. (2002). Isolation and characterization of high molar mass watersoluble arabinoxylans from barley and barley malt. Carbohydrate Polymers. 47(2): 143-149.

Doublier, J. L. and Wood, P. J. (1995). Rheological properties of aqueous solutions of (1 3),(1 4)- $\beta$ D-glucan from oats (Avena sativa L.). Cereal Chem. 72: 335-340.

Drzikova, B., Dongowski, G., Gebhardt, E., and Habel, A. (2005). The compo- sition of dietary fiber-rich extrudates from oat affects bile acid binding and fermentation in vitro. Food Chemistry. 90: 181192.

Dziezak, J. D. (1987). Yeasts and yeast derivatives. Applications in Food Tech- nol. 41: 122-125.

Elaine, R., Carbonero, A., Helena, P., Gracher, F., Smiderle, R., Fa'bio, R., Rosado, R., Guilherme, L.S., Philip, A., Gorin, J., and Marcello, I. (2006). A $\beta$-glucan from the fruit bodies of edible mushrooms Pleurotus eryngii and Pleurotus ostreatoroseus. Carbohydrate Polymers 66(2): 252-257.

Evers, T. and Millart, S. (2002). Cereal grain structure 
and development: some implications for quality. J Cereal Sci. 36: 261-284.

FAO (2001). Food balance sheet-excluding beer. FAOSTAT database $(7.1 .03,2003)$.

Faraj, A., Vasanthan, T., and Hoover, R. (2006). The influence of a-amylase- hydrolysed barley starch fractions on the viscosity of low and high purity barley $\beta$-glucan concentrates. Food Chem. 96: 56-65.

FDA (1997). Final rule for food labelling: Health claims: Oats and coronary heart disease. Federal Regulations. 62: 3584-3681.

FDA (1996). Food labeling: Health claims: Oats and coronary heart disease. Food and Drug Administration, proposed rule. Fed. Regist. 61: 296-313.

Flander, L., Salmenkallio-Marttila, M., Suortti, T., and Autio, K. (2007). Op- timization of ingredients and baking process for improved wholemeal oat bread quality. LWT 40: 860-870.

Fliegmann, J., Mithoffer, A., Wanner, G., and Ebel, J. (2004). An ancient enzyme domain hidden in the putative $\beta$-glucan elicitor receptor of soybean may play an active part in the perception of pathogen-associated molecular patterns during broad host resistance. J. Biol. Chem. 279: 11321140 .

Fliegmann, J., Montelb, E., Djulicc’a, A., Cottazb, S., Driguezb, H., and Ebela, J. (2005). Catalytic properties of the bifunctional soybean b-glucanbinding protein, a member of family 81 glycoside hydrolases. FEBS Letters. 579: 66476652.

Freimund, S., Sauter, M., Ka“ppeli, O., and Dutler, H. (2003). A new non- degrading isolation process for 13 - $\beta$-D-glucan of high purity from baker's yeast Saccharomyces cerevisiae. Carbohydrate Polymers. 54(2): 159-171.

Frey, T., Cosio, E. G., and Ebel, J. (1993). Affinity purification and character- ization of a binding protein for a hepta- $\beta$-glucoside phytoalexin elicitor in soybean. Phytochemistry. 32: 543550.

Gardiner, T. (2004). Beta-glucan biological activities: A review. 1-39. Accessed on August 7, 2005 from Internet: www.usa.glycoscience.

Genc, H., Ozdemir, M., and Demirbas, A. (2001). Analysis of mixed-linked (1 3), (1 4$)-\beta$-Dglucans in cereal grains from Turkey. Food Chem. 73:221-224.

Giese, J. H. (1992). Hitting the spot: Beverages and beverage technology. Food Technol. 46: 70-80.

Granfeldt, Y., Nyberg, L., and Bjoa“rck, I. (2008). Muesli with $4 \mathrm{~g}$ oat $\beta$-glucans lowers glucose and insulin responses after a bread meal in healthy subjects. Euro. J. Clini. Nut. 62: 600-607.
Guille'n, D., Sa'nchez, S., and Rodr'1guez-Sanoja, R. (2010). Carbohydrate- binding domains: multiplicity of biological roles. Appl Microbiol Biotechnol. 85: 1241-1249.

Gi-Young, K., Hyung-Sik, P., Byong-Hyok, N., SangJun, L, and Jae-Dong, L. (2003). Purification and characterization of acidic proteo-heteroglycan from the fruiting body of Phellinus linteus. Teng. Bioresource Tech. 89: 81-87.

Hallfrisch, J. and Behall, K. M. (1997). Evaluation of foods and physiological responses to menus in which fat content was lowered by replacement with Oatrim. Cereal Foods World. 43: 100-103.

Hallfrisch, J. and Behall, K. M. (2000). Improvement in insulin and glucose responses related to grains. Cereal Foods World. 45: 66-69.

Hallfrisch, J., Schofield, D. J., and Behall, K. M. (2003). Physiological responses of men and women to barley and oat extracts (NutrimX). II. Comparison of glucose and insulin responses. Cereal Chem. 80: 80-83.

Han, J. Y. (2000). Structural characteristics of arabinoxylan in barley, malt, and beer. Food Chem. 70(2): 131-138.

Han, J. Y. and Schwarz, P. B. (1996). Arabinoxylan composition in barley, malt, and beer. $J$. of the American Soc. of Brewing Chem. 54(4): 216220.

Hlebowicz, J., Darwiche, G., Bjo“rgell, O., and Alme’r, L. (2008). Effect of Muesli with $4 \mathrm{~g}$ Oat $\beta$-glucan on postprandial blood glucose, gastric emptying and satiety in healthy subjects: A randomized crossover trial. J. Am. Coll. Nut. 27(4): 470-475.

Holtekjølen, A. K., Uhlen, A. K., Braøthen, E., Sahlstrøm, S. , and Knutsen, S.H. (2006). Contents of starch and non-starch polysaccharides in barley varieties of different origin. Food Chemistry. 94: 348-358.

Honnavally, P., Ramesh, R., and Tharanathan, N. (1998). Structural charac- teristics of a mixed linkage $\beta$-D-glucan from sorghum (Sorghum bicolor). Carbohydrate Res. 308(1-2): 239-243.

Hrmova, M., Banik, M., Harvey, A. J., Garrett, T. P. J., Varghese, J. N., Hoj, P. B., and Fincher, G. B. (1997). Polysaccharide hydrolases in germinated barley and their role in the depolymerization of plant and fungal cell walls. Int. J. Biol. Macromol. 21: 67-72.

Immerstrand, T., Bergensta ${ }^{\circ}$ hl, B., Tra“ga ${ }^{\circ}$ rdh, C., Nyman, M., Cui, S., and O* ste, R. (2009). Extraction of $\beta$-glucan from oat bran on laboratory scale. Cereal Chem. 86(6): 601-608.

Inglett, G. E., Carriere, C. J., Maneepun, S., and Tungtrakul, P. (2004). A soluble fiber gel produced from rice bran and barley flour as a fat replacer in Asian foods. International Journal of 
Food Sci. and Tech. 39: 1-10.

Irakli, M., Biliaderis, C. G., Izydorczyk, M. S., and Papadoyannis, I. N. (2004). Isolation, structural features and rheological properties of waterextractable $\beta$-glucans from different Greek barley cultivars. J. Sci. Food Agric. 84: 1170-1178.

Izawa, M., Kano, Y., and Koshino, S. (1993). Relationship between structure and solubility of (1 3),(1 4)- $\beta$-glucan from barley. J. Am. Assoc. Brew. Chem. 51(3): 123-127.

Izydorczyk, M. S., Jacobs, M., and Dexter, J. E. (2003). Distribution and struc- tural variation of non-starch polysaccharides in milling fractions of hull-less barley with variable amylase content. Cereal Chem. 80: 6445-6653.

Izydorczyk, M. S. and Biliaderis, C. G. (2000). Structural and functional aspects of cereal arabinoxylans and b-glucans. In: Doxastakis, G. and Kiosseoglou, V. (Eds.), Novel Macromolecules in Food Systems. Elsevier Science B.V., Amsterdam, pp. 361-384.

Izydorczyk, M. S., Storsley, J., Labossiere, D., MacGregor, A. W., and Ross- nagel, B.G. (2000). Variation in total and soluble $\beta$-glucan content in hulless barley: Effects of thermal, physical, and enzymic treatments. J. of Agric. and Food Chem. 48: 982-989.

Jackson, C. and Barth, H. G. (1995). Concerns regarding the practice of multiple detector sizeexclusion chromatography. Adv. Chem. Ser. 247: 59-68.

Jadhav, S. J., Lutz, S. E., Ghorpade, V. M., and Salunkhe, D. K. (1998). Barley: Chemistry and value-added processing. Critical Rev. in Food Sci. and Nutr. 38(2): 123-171.

Jenkins, A. L., Jenkins, D. J. A., Zdravkovic, U., Wu"rsch, P., and Vuksan, V. (2002). Depression of the glycemic index by high levels of $\beta$-glucan fiber in two functional foods tested in type-2 diabetes. Eur. J. Clin. Nutr. 56: 622-628. Jinshui, W., Cristina, M. R., and De-Barbera, C. B. (2002). Effect of the addition of different fibers on wheat dough performance and bread quality. Food Chem.79: 221-226.

Jørgensen, K. G. (1988). Quantification of high molecular weight (1 3$)\left(\begin{array}{ll}1 & 4\end{array}\right)$ - $\beta$-D-glucan using Calcofluor complex formation and flow injection analysis. I. Analytical principle and its standardization. Carlsberg Res Commun. 53: 277-285.

Jung, H., Kim, A., and White, P. J. (2010). In vitro bile-acid binding and fermentation of high, medium, and low molecular weight $\beta$-glucan. $J$. Agric. Food Chem. 58: 628-634.

Kalinga, D. and Mishra, V. K. (2009). Rheological and physical properties of low fat cakes produced by addition of cereal $\beta$-glucan concentrates. Journal of Food Processing and Preservation 33(3): 384-400.

Kanauchi1, M. and Bamforth, C. W. (2001). Release of $\beta$-Glucan from cell walls of starchy endosperm of barley. Cereal Chem. 78(2): 121-124.

Kang, S. A., Jang, K. H., Hong, K., Choi, W. A., and Lee, I.Y. (2003). Effects of dietary beta-glucan on serum lipids and leptin levels in the dietinduced obese rats. FASEB Journal 17: A1141.

Karaduman, D., Eren, B., and Keles, O. N. (2010). The protective effect of beta-1,3-D-glucan on taxolinduced hepatotoxicity: A histopathological and stereological study. Drug and Chem. Toxicol. 33(1): 8-16.

Ken-ichi, I., Noriko, N., Miura, Y.A., Hiroshi, T., Shigenori, T. and Naohito, O. (2004). The solubilization and biological activities of Aspergillus $\beta$-(1 3)- D- glucan. FEMS Immunol. and Med. Microbiol. 42(1): 155-166.

Kerckhoffs, D. A. J. M., Hornstra, G., and Mensink, R. P. (2003). Cholesterol lowering effect of $\beta$ glucan from oat bran in mildly hypercholersterolemic subjects may decrease when $\beta$-glucan is incorporated into bread and cookies. American J. of Clinical Nutr. 78: 221227.

Kim, Y. W., Kim, K. H., Choi, H. J., and Lee, D. S. (2005). Anti-diabetic activity of beta-glucans and their enzymatically hydrolyzed oligosaccharides from Agaricus blazei. Biotechnol. Lett. 7(7): 483-487.

Kim, H. J., and White, P. J. (2010). In vitro bile-acid binding and fermentation of high, medium, and low molecular weight $\beta$-glucan. J. Agric. Food Chem. 58(1): 628-634.

Kjell, M., Va ${ }^{\circ}$ rum, and Olav, S. (1988). Partial chemical and physical character- ization of (1 3),(1 4)- $\beta$-D-glucans from oat (Avena sativa L.) aleurone. Carbohydrate Polymers. 9(2): 103117.

Konuklar, G., Inglett, G.E., Warner, K., and Carriere, C.J. (2004). Use of a $\beta$-glucan hydrocolloidal suspension in the manufacture of low-fat cheddar cheeses: textural properties by instrumental methods and sensory panels. Food Hydrocolloids. 18: 535-545.

Lazaridou, A., Biliaderis, C. G., Micha-Screttas, M., and Steele, B. R. (2004). A comparative study on structure-function relations of mixed linkage (1 3) linear $\beta$-D-glucan. Food Hydrocolloids. 18: 837-855.

Lazaridou, A., and Biliaderis, C. G. (2004). Cryogelation of cereal $\beta$ - glucans: Structure and molecular size effects. Food Hydrocolloids. 18: 
933-947.

Lazaridou, A., Biliaderis, C. G., and Izydorczyk, M. S. (2003). Molecular size effects on rheological properties of oat $\beta$-glucans in solutions and gels. Food Hydrocolloids. 17: 693-712.

Lazaridou, A., Duta, D., Papageorgiou, M., Belc, N., and Biliaderis, C. G. (2007). Effects of hydrocolloids on dough rheology and bread quality param- eters in gluten-free formulations. J. of Food Engin. 79: 1033-1047.

Lehtonen, M. and Aikasalo, R. (1987). Pentosans in barley varieties. Cereal Chemistry. 64(2): 133134.

Levin, D. E. and Bartlett-Heubusch. E. (1992). Mutants in the $S$. cerevisiae PKC1 gene display a cell cycle-specific osmotic stability defect. J. Cell Biol. 116: 1221-1229.

Li, J., Kaneko, T., Qin, L. Q., Wang, J., and Wang, Y. (2003). Effects of barley intake on glucose tolerance, lipid metabolism, and bowel function in women. Nutrition. 19: 11-12.

Lia, W., Wanga, Q., Cuia, S.W., Huanga, X., and Kakudab, Y. (2006). Elimina- tion of aggregates of (1 3) (1 4) - $\beta$-D-glucan in dilute solutions for light scattering and size exclusion chromatography study. Food Hydrocolloids. 20: 361-368.

Liu, S., Mansin, J. E., and Stampfer, M. J. (2000). Whole grain consumption and risk of ischemic stroke in women. J. A. M. A. 284: 1534-1540.

Liu, W., Zhang, B., Wang, Q., Xie, Z., Yao, W., Gao, $X$., and Yu, L. (2010). Effects of sulfation on the physicochemical and functional properties of psyl- lium. J. Agric. Food Chem. 58: 172-179.

Lyly, M., Marttila, M.S., Suortti, T., Autio, K., Poutanen, K., and Liisa L. (2004). The sensory characteristics and rheological properties of soups containing oat and barley b-glucan before and after freezing. Lebensm.-Wiss. U.-Technol. 37: 749-761.

Lyly, M., Roininen, K., Honkapaa, K., Poutanen, K., and Lahteenmaki, L. (2007). Factors influencing consumers willingness to use beverages and ready-to-eat frozen soups containing oat b-glucan in Finland, France and Sweden. Food Quality and Preference. 18: 242-255.

Lyly, M., Salmenkallio, M., Suortti, M., Autio, K., Poutanen, K., and Lahteenmaki, L. (2003). Influence of oat $\beta$-glucan preparations on the percep- tion of mouth feel and rheological properties in beverage prototypes. Cereal Chem. 80: 536-541.

MacGregor, A. W. and Rattan, S. (1993). Barley: Chemistry and Technology. American Association of Cereal Chemists Inc., St. Paul, Minnesota.
Magda, F., Tomoya, I., Vincent, B., and Antoni P. (2004). In vitro synthesis of a crystalline (1 3, 1 $4)-\beta$-D-glucan by a mutated (1 3, 14)- $\beta$-Dglucanase from Bacillus. Biochemical Journal. Ms. BJ20040145.

Ma"lkki, Y. and Virtanen, E. (2001). Gastrointestinal effects of oat bran and oat gum: A review. Lebensmittel-Wissenschaft und -Technologie. 34: 337-347.

Mekis, E. Pinter, G., and Bendek, G. (1987). Modified fluorometric flow- injection-analysis (FIA) method for the determination of (1 3) (14)$\beta$-glucan. J. Inst. Brew. 93: 396-398.

Meyer, K. A., Kushi, L. H., Jacobs, D.R., Slavin, Jr, J., Sellers, T.A., and Folsom, A.R. (2000). Carbohydrates, dietary fiber, and incident type 2 diabetes in older women. Am. J. Clin. Nutr. 71: 921-925.

Mithofer, A., Lottspeich, F., and Ebel, J. (1996). Onestep purification of the $\beta$-glucan elicitor-binding protein from soybean (Glycine max L.) roots and characterization of an anti-peptide antiserum. F.E.B./Lett. 381: 203- 207.

Miura, N.N., Adachi, Y., Yadomae, T., Tamura, H., Tanaka, S., and Ohno, N. (2003). Structure and biological activities of beta-glucans from yeast and mycelial forms of Candida albicans. Microbiol Immunol. 47(3): 173- 182.

Moriartey, S., Temelli, F., and Vasanthan, T. (2010). Effect of formulation and processing treatments on viscosity and solubility of extractable barley $\beta$ - glucan in bread dough evaluated under in vitro conditions. Cereal Chem. 87(1): 65-72.

Newman, R.K. and Newman, C.W. (1991). Barley as a food grain. Cereal Food World. 36: 800-805.

Odes, H.S., Lazovski, H., Stern, I., and Madar, Z. (1993). Double blind trial of high dietary fiber, mixed grain cereal in patients with chronic constipation and hyperlipidaemia. Nut. Res. 13: 979-985.

Ohno, N., Miura, N.N., Nakajima, M., and Yadomae, T. (2000). Antitumor 1 3-beta-glucan from cultured fruit body of Sparassis crispa. Biol. Pharm. Bull. 23(7): 866-872.

O" stman, E., E. Rossi, H. Larsson, F. Brighenti, and I. Bjorck. (2006). Glucose and insulin response in healthy men to barley bread with different levels of (1 3) (1 4)- $\beta$-glucans; predictions using fluidity measurements of in vitro enzyme digests. J. Cereal Sci. 43: 230-235.

Ozdemir, M. and Genc, H. (2001). $\beta$-Glucan contents of cereal grains grown in Turkey. Energy Education Science and Technology. 7: 10-17.

Paliyath, G. and Poovaiah, B.W. (1988). Promotion of B-Glucan synthase activity in performance of rye samples used in Scandinavia. Acta Agr. Scand. 
47: 26-34.

Park, S. Y., Bae, I. Y., Lee, S., and Lee, H. G. (2009). Physicochemical and hypocholesterolemic characterization of oxidized oat $\beta$-glucan. Journal of Agricultural and Food Chemistry 57(2): 439-443.

Pauchet, Y., Freitak, D., Heidel-Fischer, H.M., Heckel, D.G., and Vogel, H. (2009). Immunity or digestion: Glucanase activity in a glucan-binding protein family from Lepidoptera. J. Biol. Chem. 284(4): 2214-2224.

Pomeranz, Y., Shogern, M. D., Finney, K.F., and Bechtel, D. B. (1977). Fiber in bread makingeffects on functional properties. Cereal Chem. 54: $25-41$.

Reis, R.A., Tischer, C. A., Gorin, P.A., and Iacomini, M. (2002). A new pullulan and a branched (1 3)-, (1 6)-linked beta-glucan from the lichenised ascomycete Teloschistes flavicans. F.E.M.S. Microbiol. Lett. 210(1): 1-5.

Roemer, T. and Bussey, H. (1991). Yeast beta-glucan synthesis: KRE6 encodes a predicted type II membrane protein required for glucan synthesis in vivo and for glucan synthase activity in vitro. Proc. Natl. Acad. Sci. USA. 88: 11295.

Roemer, T., Delaney, S., and Bussey, H. (1993). SKN1 and KRE6 define a pair of functional homologs encoding putative membrane proteins involved in beta-glucan synthesis. Mol. Cell. Biol. 13: 4039 4048.

Roubroeks, J. P., Andersson, R. and Åman, P. (2000). Structural features of (1 3), (1 4)- $\beta$-D-glucan and arabinoxylan fractions isolated from rye bran. Carbohydrate Polymer. 42(1): 3-11.

Rout, D., Mondal, S., Chakraborty, I., Pramanik, M., and Islam, S.S. (2005). Chemical analysis of a new (1 3)-, (1 6)-branched glucan from an edible mushroom, Pleurotus florida. Carbohydr. Res. 340(16): 2533-2539.

Rudel, H. (1990). A composition of flours containing vital gluten and soluble oat dietary fiber and a baked product. US Patent 4961937.

Santos, A., Marquina, D., Leal, J. A., and. Peinado, J. M. (2000). (1 6)- $\beta$-D- glucan as cell wall receptor for Pichia membranifaciens killer toxin. Applied and Environmental Microbiol. 66(5): 1809-1813.

Shin, M. S., Lee, S., Lee, K. Y., Lee, H. G. (2005). Structural and biological characterization of aminated-derivatized oat $\beta$-glucan. J. Agric. Food Chem. 53: 5554-5558.

Skendi, A., Papageorgiou, M., and Biliaderis, C. G. (2010). Influence of water and barley $\beta$-glucan addition on wheat dough viscoelasticity. Food Res. Int. 43(1): 57-65.
Skendi, A., Biliaderis, C.G., Papageorgiou, M., and Izydorczyk, M. S. (2010). Effects of two barley $\beta$-glucan isolates on wheat flour dough and bread properties. Food Chem. 119(3): 1159-1167.

Smiderle, F. R., Carbonero, E. R., Mellinger, C. G., Sassaki, G. L., Gorin, P. A., and Iacomini, M. (2006). Structural characterization of a polysaccharide and a beta-glucan isolated from the edible mushroom Flammulina velutipes. Phytochem. 67(19): 2189-2196.

Smith, K.N., Queenan, K., Thomas, W., Fulcher, G., and Slavin, J. (2004). Cholesterol-lowering effect of barley beta-glucan in hypercholesterolemic subjects. F.A.S.E.B Journal. 18:149-152.

Staudte, R.G., Woodward, J.R., Fincher, G.B., and Stone, B.A. (1983). Water soluble (1 3), (1 4)$\beta$-glucan from barley (Hordeum vulgare) endosperm III. Distribution of cellotriosyl and cellotetraosyl residues. Carbo- hydr. Polym. 3: 299-312.

Storsley, J. M., Izydorczyk, M. S., You, S and Biliaderis, C. G. (2003). Structure and physicochemical properties of $\beta$-glucans and arabinoxylans isolated from hull-less barley. Food Hydrocolloids. 17(6): 831-844.

Sudha, M.L., Vetrimani, R., and Leelavathi, K. (2007). Influence of fiber from different cereals on the rheological characteristics of wheat our dough and on biscuit quality. Food Chem. 100: 13651370.

Sugawara, T., Takahashi, S., Osumi, M., and Ohno, N. (2004). Refinement of the structures of cell-wall glucans of Schizosaccharomyces pombe by chem- ical modification and NMR spectroscopy. Carbohydr Res. 339(13): 2255-2265.

Suphantharika, M., Khunrae, P., Thanardkit, P., and Verduyn, C. (2003). Prepa- ration of spent brewer's yeast beta-glucans with a potential application as an immunostimulant for black tiger shrimp. Penaeus monodon.Bioresour Technol. 88(1): 55-60.

Svihus, B., Selmer-Olsen, I., and Brathen, E. (1995). Effect of different preserva- tion methods for high-moisture barley on feeding value for broiler-chickens. Acta Agriculturae Scandinavica, Section A: Animal Science. 45(4): 252-259.

Temelli, F., Bansema, C. B., and Stobbe, K. S. (2004). Development of an orange-flavored barley $\beta$ Glucan beverage with added whey protein isolate. J. of Food Sci. 69(7): 237-242.

Thondre, P. and Henry, C. (2009). High-molecularweight barley $\beta$-glucan in chapatis (unleavened Indian flatbread) lowers glycemic index. Nut. Res. 29(7): 480-486.

Trogh, I., Courtin, C. M., Andersson, A.A.M., Man, A. 
P., Sorensen, J. F., and Delcour, J. A. (2004). The combined use of hull-less barley flour and xylanase as a strategy for wheat/hull-less barley flour breads with increased arabinoxy- lan and (1 3) (1 4)- $\beta$-D-glucan levels. J. Cereal Sci., 40: 257-267.

Truswell, A. S. (2002). Cereal grains and coronary heart disease. Eur. J. Clin. Nutr. 56: 1-3.

Tudorica, C.M., Jones, E., Kuri, V., and Brennan, C. S. (2004). The effects of refined barley $\beta$-glucan on the physico-structural properties of low-fat dairy products: curd yield, microstructure, texture and rheology. J. of Sci. of Food and Agric. 84: 11591169.

Tungland, B. C. (2003). Fructo oligosaccharides and other fructans: structures and occurrence, production, regulatory aspects, food applications, and nutri- tional health significance. ACS Symposium Series. 849: 135-152.

Tungland, B.C. and Meyer, D. (2002). Nondigestible olig-and polysaccharides (dietary fiber): Their physiology and role in human health and food. Compr. Rev. in Food Sci. and Food Safety. 1: 73-92.

Umemoto, N., Kakitani, M., Iwamatsu, A., Yoshikawa, M., Yamaoka, N., and Ishida, I. (1997). The structure and function of a soybean beta-glucanelicitor- binding protein. Proc. Natl. Acad. Sci. 94: 1029-1034.

Vaikousi, H., Biliaderis, C. G., and Izydorczyk, M. S. (2004). Solution flow behaviour and gelling properties of water-soluble barley (1 3), (1 4)- $\beta$ glucans varying in molecular size. Journal of Cereal Sci. 39: 119-137.

Valle-Jones, J. C. (1985). An open study of oat bran meal biscuits (Lejifiber) in the treatment of constipation in the elderly. Current Med. Res. and Opinion. 9: 716-720.

Warren, R. A. J. (1996). Microbial hydrolysis of polysaccharides. Annu. Rev. Microbiol. 50:183212.

Wei, L., Steve, W., Cui, and Yukio, K. (2006). Extraction, fractionation, struc- tural and physical characterization of wheat $\beta$-D-glucans. Carbohydrate Poly- mers 63(3): 408-416.

White, D.R. Jr. (1999). Applications of gel permeation chromatography with multiple light scattering to the characterization of polysaccharides. In: Polysaccharide Applications, Cosmetics, and Pharmaceuticals, pp. 299-316, El-Nokaly, M.A. and Soini, H.A., Eds., American Chemical Society, Wash- ington, D.C.

WHO (2001). Joint FAO/WHO food standards programme. Report of the 23rd Session of the Codex Committee on Nutrition and Foods for Special Dietary Uses. Berlin, Germany, p. 70.
WHO (2003). Diet, nutrition and the prevention of chronic diseases. Report of a Joint WHO/FAO Expert Consultation. WHO Technical Report Series 916, Geneva.

Wisker, E., Daniel, M., Rave, G., and Feldeim, W. (2000). Short chain fatty acids produced in vitro from fiber residues obtained from mixed diets containing different breads and in human feces during ingestion of diets. British J. of Nutr. 84: 31-37.

Wood, P. J. and Weisz, J. (1984). Use of calcofluor in analysis of oat beta-D- glucan. Cereal Chem. 61(1): 73-75.

Wood, P.J., Weisz, J., and Blackwell, B.A. (1994). Structural studies of (1 3 ) (1 4)- $\beta$-D-glucans by $13^{\mathrm{C}}$-NMR by rapid analysis of cellulose-like regions using high-performance anion-exchange chromatography of oligosac- charides released by lichenase. Cereal Chem. 71: 301-307.

Wood, P.J. (1980). The interaction of direct dyes with water soluble substituted celluloses and cereal $\beta$ glucans. Ind. Eng. Prod. Rev. Dev. 19: 19-23.

Wood, P.J. (1993). Physicochemical characteristics and physiological properties of oat (1 3) (1 4) - $\beta$-Dglucan. In: Oat Bran, pp. 83-112, Wood, P.J., Ed., AOAC, St. Paul, MN.

Wood, P. J., Weisz, J., and Mahn, W. (1991). Molecular characterization of cereal $\beta$-D-glucans II. Size exclusion chromatography for comparison of molecular weight. Cereal Chem. 68: 530-536.

Wood, P.J., Beer, M., and Butler, U. (2000). Evaluation of role of concentration of molecular weight of oat $\beta$-glucan in determining effect of viscosity on plasma glucose and insulin following an oral glucose load. British J. of Nutr. 84: 19-23.

Wood, P.J. (2001). Cereal $\beta$-glucans: Structure, properties and health claims. In: Advanced Dietary Fiber Technology, pp. 315-327, McCleary, B.V. and Prosky, L., Eds., Blackwell Science, London.

Woodward, J. R., Fincher, G. B., and Stone, B. A. (1983). Water-soluble (1 3), (1 4)- $\beta$-glucan from barley (Hordeum vulgare) endosperm II. Finestruc- ture. Carbohydrate Polym. 3: 207225.

Wyatt, P. J. (1993). Review: Light scattering and the absolute characterization of macromolecules. Analytica Chimica Acta. 272: 1-40.

Yalin, W., Yuanjiang, P., and Cuirong, S. (2005). Isolation, purification and struc- tural investigation of a water-soluble polysaccharide from Solanum lyratum Thunb. .Int. J. Biol. Macromol. 36(4): 241-245. 
Yang, J. L., Kim, Y. H., Lee, H. S., Lee, M. S., and Moon, Y. K. (2003).

Barley beta-glucan lowers serum cholesterol based on the up-regulation of cholesterol 7-alphahydroxylase activity and mRNA abundance in cholesterol fed rats. Journal of Nutritional Science and Vitaminology. 49: 381-387.

Yokoyama, W. H., Hudson, C. A., Knucles, B. E., Chiu, M. C. M., Sayre, R. N., Turnlund, J. R., and Schneeman, B. O. (1997). Effect of barley $\beta$ - glucan in durum wheat pasta on human glycemic response. Cereal Chem. 74: 293-296.

Yun-Hyoung, Y., Eun-Young, K., Mi-Kyoung, K., Han-Young, C., Mee-Ree, K. (2006). Physicochemical and sensory characteristics of milk bread substituted with high amount of betaGlucan. Korean J. Food and Cookery Sci. 22(2): 04-212.

\section{How to cite this article:}

Mushtaq Ahmad, Shahida Iqbal, Rizvan Rashid, Nagmana Gul, Baba Ahmad Jahangir, Rukhsar Ahmad Dar, Showkat Ahmad Dar and Rohie Hassan. 2020. Beta Glucan: A Valuable Functional Ingredient in Foods. Int.J.Curr.Microbiol.App.Sci. 9(12): 3362-3382. doi: https://doi.org/10.20546/ijcmas.2020.912.401 